1,2 Centre for Agricultural Landscape and Land Use Research Müncheberg (ZALF), Institute of Primary Production and Microbial Ecology, Gutshof 7, D 14641 Paulinenaue ${ }^{1}$, Müncheberg², Germany

${ }^{3}$ DSMZ - German Collection of Microorganisms and Cell Cultures, Braunschweig, Germany

\section{Description of Microbacterium foliorum sp. nov. and Microbacterium phyllosphaerae sp. nov., isolated from the phyllosphere of grasses and the surface litter after mulching the sward, and reclassification of Aureobacterium resistens (Funke et al. 1998) as Microbacterium resistens comb. nov.}

\author{
Undine Behrendt, ${ }^{1}$ Andreas Ulrich ${ }^{2}$ and Peter Schumann ${ }^{3}$ \\ Author for correspondence: Undine Behrendt. Tel: +49 33237 849357. Fax: +49 33237849226. \\ e-mail: ubehrendt@zalf.de
}

The taxonomic position of a group of coryneform bacteria isolated from the phyllosphere of grasses and the surface litter after sward mulching was investigated. On the basis of restriction analyses of 165 rDNA, the isolates were divided into two genotypes. According to the $16 \mathrm{~S}$ rDNA sequence analysis, representatives of both genotypes were related at a level of $99 \cdot 2 \%$ similarity and clustered within the genus Microbacterium. Chemotaxonomic features (major menaquinones MK-12, MK-11 and MK-10; predominating isoand anteiso-branched cellular fatty acids; G+C content 64-67 mol\%; peptidoglycan-type B2 $\beta$ with glycolyl residues) corresponded to this genus as well. DNA-DNA hybridization studies showed a reassociation value of less than $70 \%$ between representative strains of both subgroups, suggesting that two different species are represented. Although the extensive morphological and physiological analyses did not reveal any differentiating feature for the genotypes, differences in the presence of the cell-wall sugar mannose enabled the subgroups to be distinguished from one another. DNA-DNA hybridization with type strains of closely related Microbacterium spp. indicated that the isolates represent two individual species, which can also be differentiated from previously described species of Microbacterium on the basis of biochemical features. As a result of phenotypic and phylogenetic analyses, the species Microbacterium foliorum sp. nov., type strain P $333 /$.02 $^{\top}$ (= DSM $12966^{\top}$ $=$ LMG $\left.19580^{\top}\right)$, and Microbacterium phyllosphaerae sp. nov., type strain $P$ $369 / 06^{\top}$ ( = DSM $13468^{\top}=$ LMG $19581^{\top}$ ), are proposed. Furthermore, the reclassification of Aureobacterium resistens (Funke et al. 1998) as Microbacterium resistens (Funke et al. 1998) comb. nov. is proposed.

Keywords: Microbacterium foliorum sp. nov., Microbacterium phyllosphaerae sp. nov., plant-associated, phenotypic and phylogenetic analysis, Microbacterium resistens comb. nov.

\section{INTRODUCTION}

Strains of the genus Microbacterium are widespread and can be isolated from different sources (Collins \&
Bradbury, 1992). The above-ground parts of plants have also been reported as a habitat of such bacteria possessing the group B type of peptidoglycan. Thompson et al. (1993) and Legard et al. (1994)

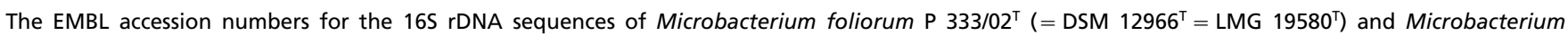
phyllosphaerae P $369 / 06^{\top}$ (= DSM $13468^{\top}=$ LMG 19581') are AJ249780 and AJ277840, respectively. 
isolated strains of the species Microbacterium lacticum, Microbacterium liquefaciens and Microbacterium saperdae from the phyllospheres of sugar beet (Beta vulgaris) and spring wheat (Triticum aestivum). McInroy \& Kloepper (1995) detected strains of Microbacterium spp. as well as Aureobacterium spp. living endophytically in sweet corn (Zea mays) and cotton (Gossypium hirsutum). However, the species of the genus Aureobacterium were accommodated in the genus Microbacterium as a consequence of a thorough taxonomic reinvestigation of these organisms (Takeuchi \& Hatano, 1998a). Coincidental with this reclassification of Aureobacterium species, a new species of this genus, Aureobacterium resistens, was described (Funke et al., 1998) and therefore could not be included in the study of Takeuchi \& Hatano (1998a). Although $A$. resistens displays all the taxonomic characteristics of the redefined genus Microbacterium, the reclassification of $A$. resistens as Microbacterium resistens comb. nov. is still pending.

In the course of studying the composition of phyllosphere microbial communities of grasses and the microbes in decaying surface litter after sward mulching, a group of bacterial isolates with characteristics similar to those of the genus Microbacterium was also found. Conventional physiological and morphological tests did not permit an affiliation at the species level. Consequently, 16S rDNA sequence analysis and DNA-DNA hybridization studies were necessary to determine the phylogenetic relationships of these bacteria. Thus, 23 strains were randomly selected from different plots and/or sampling dates for phenotypic and phylogenetic characterization to determine their taxonomic position unambiguously.

\section{METHODS}

Bacterial strains and cultivation. The bacterial strains examined in this study were isolated from grasses and surface litter, as described previously (Behrendt et al., 1997). The histories and corresponding numbers of the isolates and type strains of Microbacterium spp. and A. resistens used for comparative studies are listed in Table 1. General laboratory cultivation was performed on nutrient agar II (SIFIN) or in nutrient broth II (SIFIN) at $25^{\circ} \mathrm{C}$ unless otherwise stated. Stocks of all cultures were maintained at $-79^{\circ} \mathrm{C}$, using the Microbank storage system (Pro-Lab Diagnostics).

Morphological, physiological and biochemical characterization. Cell morphology was determined by light microscopy after 24 and $72 \mathrm{~h}$ cell growth. The motility of cells was tested by using the hanging-drop method and staining of flagella, according to the method described by Rudolph \& Marvidis (1990). The Gram reaction was tested by using the classical staining procedure, as described by Süßmuth et al. (1987). The rapid $\mathrm{KOH}$ string test (Ryu, 1938), growth on MacConkey agar (Merck), and the test for L-alanine aminopeptidase (Bactident test strips; Merck) were also applied. Most tests for characterizing the biochemical profiles of studied strains were performed as described previously (Behrendt et al., 1999). The production of acetoin (the Voges-Proskauer reaction) was determined according to Süßmuth et al. (1987). The hydrolysis of Tween 60, Tween
80, and starch was assayed according to Sands (1990). Growth on TTC and CNS medium was tested according to Vidaver \& Davis (1994). The capacity for anaerobic growth was tested using Anerocult A (Merck). API 20NE (bioMérieux) and the API 50CH gallery using the API CHE suspension medium (bioMérieux) were applied to determine additional physiological and biochemical characteristics.

Cluster analysis of physiological features was performed by using the unweighted pair group arithmetic average-linkage algorithm method, which was based on Pearson correlation or squared Euclidean distances (Sneath \& Sokal, 1973).

Determination of chemotaxonomic characteristics. Methods for the determination of peptidoglycan structure, menaquinone patterns and DNA base composition have been described previously (Groth et al., 1999). The peptidoglycan structure was elucidated by two-dimensional ascending TLC of amino acids and peptides in cell-wall hydrolysates on cellulose plates. Menaquinones were analysed by reversedphase HPLC. G + C contents were determined by HPLC of nucleosides. The determination of the glycolate content was performed according to the colorimetric method of Uchida et al. (1999). Fatty acid methyl esters were analysed by GC as described by Stead et al. (1992). Sugars in cellwall hydrolysates were analysed by TLC as described by Komagata \& Suzuki (1987).

16S rDNA sequence determination and phylogenetic analysis. Restriction analyses of amplified $16 \mathrm{~S}$ rDNA were performed as described previously (Behrendt et al., 1999). For 16S rDNA sequence determination, total DNA of the representative strains $\mathrm{P} 333 / 02^{\mathrm{T}}$ and $\mathrm{P} 369 / 06^{\mathrm{T}}$ was obtained. Cells grown overnight in $2 \mathrm{ml}$ media were washed with TE buffer (10 mM Tris/HCl, pH 8.0; 1 mM EDTA) and frozen in liquid nitrogen. The frozen cells were crushed using a glass pistil, and the lysate was resuspended in $200 \mu \mathrm{TE}$ buffer. Further purification was carried out using the QIAamp Blood Kit (Qiagen) according to the manufacturer's instructions. The $16 \mathrm{~S}$ rDNA was amplified with $P f u$ DNA polymerase (Promega) and cloned into the vector PCR4Blunt-TOPO using the Zero Blunt TOPO cloning kit for sequencing (Invitogen). A cycle sequencing protocol was applied for sequencing both complementary strands with a Li-Cor Sequencer (model 4200; MWG Biotech). The similarity values were based on pairwise comparisons of sequences. For phylogenetic analyses, the DNA sequences were aligned using the CLUSTAL W algorithm (program version 1.74; Thompson et al., 1994) and the trees were constructed using the neighbour-joining and maximumlikelihood algorithms (PHYLIP computer program package, version 3.57; Felsenstein, 1993). The neighbour-joining algorithm (NEIGHBOR; Saitou \& Nei, 1987) is based on a matrix of pairwise distances corrected for multiple base substitutions by the method of Kimura (1980) (DNADIST with a transition/transversion ratio of 2.0). The maximumlikelihood method (DNAML; Felsenstein, 1981) was applied with three jumbles of the dataset and without global rearrangement. The $16 \mathrm{~S}$ rDNA sequence of Clavibacter michiganensis was used as the outgroup in both calculations. The neighbour-joining tree was generated using the original dataset as well as 100 bootstrap datasets to evaluate its topology.

DNA-DNA hybridization. DNA-DNA similarity was examined for P 333/02 ${ }^{\mathrm{T}}$, P 369/06 ${ }^{\mathrm{T}}$, P 439/06, P 449/03, $A$. resistens and the type strains of Microbacterium spp., as listed in Table 1, according to the spectrophotometric method used by Martin et al. (1997). 
Table 1. Bacterial strains used in this study

Abbreviations: DSM, Deutsche Sammlung von Mikroorganismen und Zellkulturen, Braunschweig, Germany; ATCC, American Type Culture Collection, Manassas, VA, USA; CCM, Czech Collection of Microorganisms, Masaryk University, Brno, Czech Republic; CCEB, Institute of Entomology, CSAV Czechoslovak Academy of Sciences, Dept of Insect Pathology, Prague, Czech Republic; CCUG, Culture Collection, University of Göteborg, Göteborg, Sweden; CIP, Collection de l'Institut Pasteur, Paris, France; IFO, Institute for Fermentation, Osaka, Japan; JCM, Japan Collection of Microorganisms, Institute of Physical and Chemical Research, Hirosawa, Wako-shi, Japan; NCDO (= NCFB), National Collection of Food Bacteria, Aberdeen, UK; NCIB $(=\mathrm{NCIMB}=\mathrm{NCMB})$, National Collection of Industrial and Marine Bacteria, Aberdeen, UK.

\begin{tabular}{|c|c|c|c|}
\hline Isolate no./species* & Collection number(s) & Source & Isolation date \\
\hline P $206 / 02$ & - & Phyllospheres of grasses & $20 / 04 / 93$ \\
\hline P $286 / 08$ & - & Phyllospheres of grasses & $22 / 06 / 93$ \\
\hline P $315 / 01$ & - & Phyllospheres of grasses & $15 / 06 / 93$ \\
\hline P $333 / 02^{\mathrm{T}}$ & DSM $12966^{\mathrm{T}}$, LMG $19580^{\mathrm{T}}$ & Phyllospheres of grasses & $29 / 06 / 93$ \\
\hline P $334 / 05$ & - & Phyllospheres of grasses & $29 / 06 / 93$ \\
\hline P $369 / 06^{\mathrm{T}}$ & DSM $13468^{\mathrm{T}}$, LMG $19581^{\mathrm{T}}$ & Phyllospheres of grasses & $13 / 07 / 93$ \\
\hline P $375 / 05$ & - & Phyllospheres of grasses & $13 / 07 / 93$ \\
\hline P $403 / 11$ & - & Decaying grasses in the litter layer & $20 / 07 / 93$ \\
\hline P $416 / 01$ & - & Phyllospheres of grasses & $27 / 07 / 93$ \\
\hline P $421 / 05$ & - & Decaying grasses in the litter layer & $27 / 07 / 93$ \\
\hline P $423 / 09$ & - & Decaying grasses in the litter layer & $03 / 08 / 93$ \\
\hline P $434 / 29$, P $437 / 09$ & - & Phyllospheres of grasses & $10 / 08 / 93$ \\
\hline $\mathrm{P} 438 / 12, \mathrm{P} 439 / 06$ & - & Decaying grasses in the litter layer & $10 / 08 / 93$ \\
\hline $\mathrm{P} 444 / 21$ & - & Decaying grasses in the litter layer & $17 / 08 / 93$ \\
\hline P $447 / 09$, P $448 / 05$ & - & Phyllospheres of grasses & $24 / 08 / 93$ \\
\hline P $449 / 03$, P $449 / 26$, P $449 / 29$, P $450 / 03$ & - & Decaying grasses in the litter layer & $24 / 08 / 93$ \\
\hline P $469 / 32$ & - & Phyllospheres of grasses & $05 / 10 / 93$ \\
\hline M. aurantiacum & DSM $12506^{\mathrm{T}}$, ATCC $49090^{\mathrm{T}}$, IFO $15234^{\mathrm{T}}, \mathrm{NCFB} 2288^{\mathrm{T}}$ & Sewage & \\
\hline M. aurum & DSM $8600^{\mathrm{T}}$, ATCC $51345^{\mathrm{T}}$, IFO $15204^{\mathrm{T}}$ & Corn-steep liquor & \\
\hline M. keratanolyticum & DSM $8606^{\mathrm{T}}$, ATCC $35057^{\mathrm{T}}$, CCM $4375^{\mathrm{T}}$, CIP $103815^{\mathrm{T}}$, IFO $13309^{\mathrm{T}}$ & Soil & \\
\hline M. kitamiense & JCM $10270^{\mathrm{T}}$ & Wastewater (sugar-beet factory) & \\
\hline M. lacticum & DSM $20427^{\mathrm{T}}$, ATCC $8180^{\mathrm{T}}, \mathrm{NCDO} 747^{\mathrm{T}}, \mathrm{NCIB} 8540^{\mathrm{T}}$ & Unknown & \\
\hline M. liquefaciens & DSM $20638^{\mathrm{T}}$, ATCC $43647^{\mathrm{T}}$, NCIB $11509^{\mathrm{T}}$ & Milk & \\
\hline M. luteolum & DSM $20143^{\mathrm{T}}$, ATCC $51474^{\mathrm{T}}$, IFO $15074^{\mathrm{T}}$, NCIB $9568^{\mathrm{T}}$ & Soil & \\
\hline M. maritypicum & DSM $12512^{\mathrm{T}}$, ATCC $19260^{\mathrm{T}}$, IFO $15779^{\mathrm{T}}$, NCIMB $1050^{\mathrm{T}}$ & Sea water, marine mud & \\
\hline M. oxydans & DSM $20578^{\mathrm{T}}$, CIP $6612^{\mathrm{T}}$, NCIB $9944^{\mathrm{T}}$ & Air & \\
\hline A. resistens & DSM $11986^{\mathrm{T}}$, CCUG $38312^{\mathrm{T}}$ & Corneal ulcer & \\
\hline M. saperdae & DSM $20169^{\mathrm{T}}$, ATCC $19272^{\mathrm{T}}$, CCEB $366^{\mathrm{T}}$ & Elm borer & \\
\hline M. terregens & DSM $20449^{\mathrm{T}}$, ATCC $13345^{\mathrm{T}}$, CCM $2634^{\mathrm{T}}, \mathrm{NCIB} 8909^{\mathrm{T}}$ & Soil & \\
\hline M. testaceum & DSM $20166^{\mathrm{T}}$, ATCC $15829^{\mathrm{T}}$, CCM $2299^{\mathrm{T}}$ & Rice & \\
\hline
\end{tabular}

* Isolate nos relate to the collection at the Institute of Primary Production and Microbial Ecology, Centre for Agricultural Landscape and Land Use Research Müncheberg (ZALF), Paulinenaue, Germany.

\section{RESULTS}

\section{Restriction analysis of $16 \mathrm{~S}$ rDNA}

To analyse the phylogenetic heterogeneity of the isolates (Table 1), 16S rRNA genes were amplified with primers described by Weisburg et al. (1991), resulting in a single band of approximately $1500 \mathrm{bp}$. Digestion of these PCR products (using the endonucleases TaqI, Hinf I, AluI, MspI, ScrFI and Sau3A) led to identical restriction patterns for all isolates. However, one different band per restriction pattern of the 16S rDNA sequences resulted from the endonucleases $C f_{o I}$ and HaeIII. The isolates were nearly equally divided into two genotypes, as follows: genotype I: P 315/01, P 333/02 , P 375/05, P 403/11, P 437/09, P 444/21, P 447/09, P 448/05, P 449/03, P 449/26, P 449/29, P 469/32; genotype II: P 206/02, P $286 / 08$, P 334/05, P369/06, ${ }^{\mathrm{T}}$ P 416/01, P 421/05, P 423/09, P 434/29, P 438/12, P 439/06, P 450/03). One strain of each genotype, $\mathrm{P} 333 / 02^{\mathrm{T}}$ (I) and P $369 / 06^{\mathrm{T}}$ (II), was chosen as a representative strain for certain investigations.

\section{Morphological, physiological and biochemical characteristics}

All of the isolates studied were Gram-positive, strictly aerobic, non-spore-forming, irregularly rod-shaped organisms. Some cells were arranged at angles, forming V-shapes, but primary branching was not observed. In older cultures, rods were shorter, but a marked rod-coccus growth cycle did not occur. Some cells were motile by means of a single polar or lateral flagellum.

The optimum growth temperature was $25^{\circ} \mathrm{C}$. At $37^{\circ} \mathrm{C}$, growth was strain-dependent, whereas none of the isolates was capable of growing at $42{ }^{\circ} \mathrm{C}$. On solid media, colonies were circular, slightly convex with entire margins, shiny and moist. The pigment of colonies was translucent yellow and became lemonyellow in older cultures.

Determination of the Gram reaction by means of classical staining procedures gave uncertain results for most of the strains, as they are decolorized easily and react like Gram-negative bacteria. However, the rapid 
Table 2. Physiological tests showing differing results among the 23 isolates tested

\begin{tabular}{|c|c|c|c|c|}
\hline Test & $\begin{array}{l}\text { P } 333 / 02^{\mathrm{T}}(\mathrm{I}) \\
(\text { DSM 12966 }\end{array}$ & $\begin{array}{l}\text { P } 369 / 06^{\mathrm{T}} \text { (II) } \\
\text { (DSM 13468 })\end{array}$ & $\begin{array}{c}\text { No. } \\
\text { strains }+1-\end{array}$ & Strains showing the less common response $\dagger$ \\
\hline Growth at $37^{\circ} \mathrm{C}$ & $\mathrm{w}+$ & $\mathrm{w}+$ & $15 / 8$ & $\begin{array}{l}\text { P 444/21; P 449/29; P 286/08; P 334/05; P 434/29; P 438/12; P 439/06; } \\
\text { P 450/03 }\end{array}$ \\
\hline \multicolumn{5}{|r|}{ 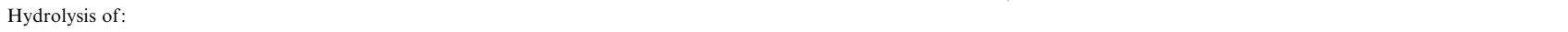 } \\
\hline Casein & - & - & $1 / 22$ & P 206/02 \\
\hline Tween 60 & + & + & $21 / 2$ & P $437 / 09 ;$ P 206/02 \\
\hline Tween 80 & - & + & $7 / 16$ & P 286/08; P 334/05; P 369/06 ${ }^{\mathrm{T}} ;$ P 434/29; P 438/12; P 439/06; P 450/03 \\
\hline Starch & $\mathrm{w}+$ & $\mathrm{w}+$ & $22 * / 1$ & Р 206/06 \\
\hline Oxidative acid production from glucose (API 20NE) & + & + & $22 / 1$ & P 438/12 \\
\hline \multicolumn{5}{|l|}{ Assimilation of: } \\
\hline Citrate & + & - & $3 / 20$ & P $333 / 02^{\mathrm{T}} ;$ P $444 / 21 ;$ P $447 / 09$ \\
\hline Phenylacetate & - & + & $3 / 20$ & P 447/09; P 369/06 ${ }^{\mathrm{T}} ; \mathbf{P}$ 421/05 \\
\hline \multicolumn{5}{|l|}{ Acid production from (API $50 \mathrm{CH}$ ): } \\
\hline D-Arabinose & - & - & $13 / 10$ & $\begin{array}{l}\text { P } 333 / 02^{\mathrm{T}} ; \text { P } 375 / 05 ; \text { P } 403 / 11 ; \text { P } 437 / 09 ; \text { P } 447 / 09 ; \text { P } 449 / 26 ; \\
\text { P 286/08; P 369/06 }{ }^{\mathrm{T}} ; \text { P 416/01; P 450/03 }\end{array}$ \\
\hline L-Arabinose & + & + & $22 / 1$ & P 206/02 \\
\hline Methyl $\alpha$-D-glucoside & - & - & $19 / 4$ & P $333 / 02^{\mathrm{T}} ;$ P $449 / 29 ;$ P 369/06 $;$; P 434/29 \\
\hline L-Fucose & + & + & $15 / 8$ & $\begin{array}{l}\text { P 444/21; P 449/26; P 286/08; P 416/01; P 421/05; P 438/12; P 439/06; } \\
\text { P 450/03 }\end{array}$ \\
\hline$\beta$-Gentiobiose & - & + & $21 / 2$ & $\mathrm{P} 333 / 02^{\mathrm{T}} ; \mathrm{P} 449 / 26$ \\
\hline Glycogen & - & - & $5 / 18$ & P $441 / 21 ;$ P $449 / 26 ;$ P 416/01; P 421/05; P 438/12 \\
\hline Inulin & - & - & $5 / 18$ & P $444 / 21 ;$ P $449 / 26 ;$ P 416/01; P 434/29; P 438/12 \\
\hline Inositol & - & - & $2 / 21$ & P $423 / 09 ;$ P 434/29 \\
\hline Lactose & - & - & $7 / 16$ & Р 444/21; Р 449/29; P 206/02; P 286/08; P 416/01; P 421/05; P 438/12 \\
\hline Methyl $\alpha$-D-mannoside & + & + & $11 / 12$ & $\begin{array}{l}\text { P } 333 / 02^{\mathrm{T}} ; \text { P } 375 / 05 ; \text { P 403/11; P 444/21; P } 449 / 26 ; \text { P } 449 / 29 ; \text { P 206/06; } \\
\text { P 369/06 }\end{array}$ \\
\hline Melibiose & - & + & $13 / 10$ & $\begin{array}{l}\text { P } 315 / 01 ; \text { P } 333 / 02^{\mathrm{T}} ; \text { P } 403 / 11 ; \text { P } 447 / 09 ; \text { P } 448 / 05 ; \text { P 469/32; P 206/02; } \\
\text { P 286/08; P 434/29 }\end{array}$ \\
\hline Melezitose & + & + & $21 / 2$ & P $449 / 29 ;$ P $434 / 29$ \\
\hline Raffinose & + & + & $21 / 2$ & Р $447 / 09 ;$ P 206/06 \\
\hline Rhamnose & + & + & $16 / 7$ & P $375 / 05 ;$ P 403/11; P 444/21; P 447/09; P 449/03; P 449/26; P 449/29 \\
\hline Ribose & + & + & $18 / 5$ & P $37505 ;$ P 403/11; P 447/09; P 423/09; P 450/03 \\
\hline Sorbitol & - & - & $2 / 21$ & P $449 / 26 ;$ P 438/12 \\
\hline Starch & - & - & $6 / 17$ & P 444/21; P 449/26; P 286/08; P 416/01; P 438/12; P 439/06 \\
\hline Xylitol & - & - & $1 / 22$ & P 206/02 \\
\hline D-Xylose & + & + & $22 / 1$ & $P$ 206/02 \\
\hline Methyl $\beta$-D-xyloside & - & - & $5 / 18$ & P $375 / 05 ;$ P $444 / 21 ;$ P 421/05; P 438/12; P 439/06 \\
\hline
\end{tabular}

* Weak hydrolysation of starch, with the exception of strain P 416/01.

$\uparrow$ Strains belonging to genotype I are indicated by the use of normal lettering; strains belonging to genotype II are indicated by bold lettering.

$\mathrm{KOH}$ string test resulted in a Gram-positive reaction, which was supported by the absence of L-alanine aminopeptidase. No growth was observed on MacConkey agar.

All strains showed positive results for catalase, $\beta$ galactosidase, DNase, aesculin and gelatin hydrolysis, as well as for growth in the presence of $2 \% \mathrm{NaCl}$. They assimilated arabinose, gluconate, glucose, malate, maltose, mannitol, mannose, $N$-acetylglucosamine and produced acid from amygdalin, arbutin, cellobiose, D-fructose, galactose, glycerol, maltose, mannitol, D-mannose, salicin, sucrose and trehalose. The following characteristics were negative for all strains: assimilation of adipate and caprate; acid production from adonitol, D-arabitol, L-arabitol, dulcitol, Dfucose, erythritol, gluconate, 2-ketogluconate, 5-ketogluconate, L-sorbose, D-tagatose and L-xylose; the oxidase reaction; reduction of nitrate to nitrite; indole production; $\mathrm{H}_{2} \mathrm{~S}$ production from sodium thiosulphate; urease; arginine dihydrolase and the VogesProskauer reaction. Oxidative and fermentative production of acid from glucose, according to the method of Hugh \& Leifson (1953) did not occur, but oxidative acid production was positive for all of the strains tested with API $50 \mathrm{CH}$ and for nearly all tested with API 20NE.

Physiological test results demonstrating the differences between the strains studied are given in Table 2. These differences did not correspond to genotype affiliations. Cluster analysis of physiological characteristics showed no clustering according to the genotypes (data not shown). The results of additional physiological tests for representative strains $\mathrm{P} 333 / 02^{\mathrm{T}}$ (I) and $\mathrm{P}$ $369 / 06^{\mathrm{T}}$ (II) also failed to reveal any discriminatory features. Growth on CNS and TTC media was positive, whereas hydrolysis of cellulose and production of levan from sucrose were negative for both strains. Thus, it was not possible to differentiate effectively between all strains of genotypes I and II on the basis of the morphological or physiological features investigated.

\section{Chemotaxonomic characteristics}

Strains P 333/02 ${ }^{\mathrm{T}}$ and P $369 / 06^{\mathrm{T}}$ were analysed with respect to their menaquinone composition, cellular fatty acid profile, cell-wall sugars and $\mathrm{G}+\mathrm{C}$ content. 


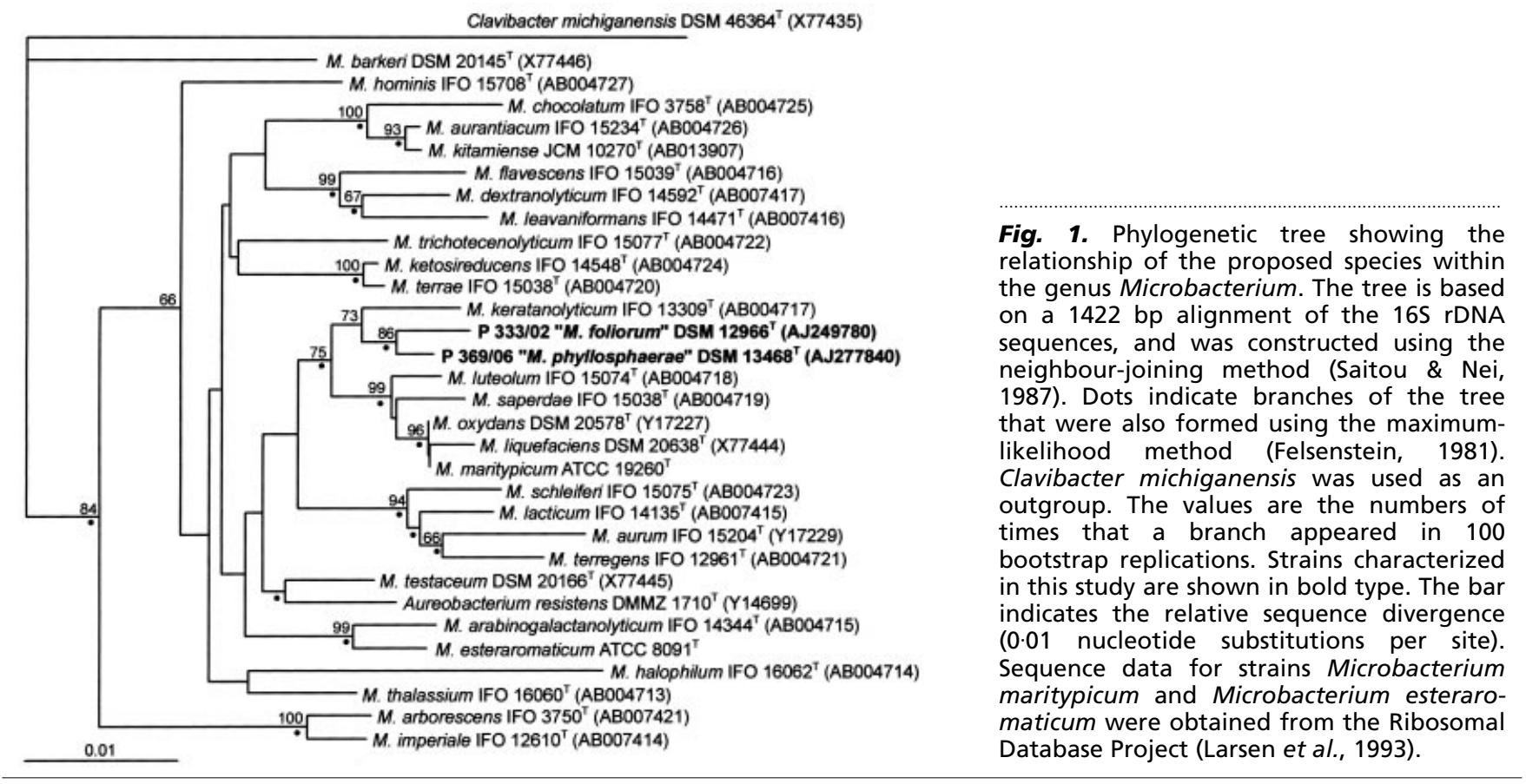

The menaquinones were fully unsaturated and ranged from MK-9 to MK-13, for P 333/02 ${ }^{\mathrm{T}}$, and from MK10 to MK-13, for P $369 / 06^{\mathrm{T}}$, respectively. MK-12 and MK-11 were the predominant menaquinones for both strains, constituting more than $70 \%$ of the peak area ratio; MK-10 followed at a value of approximately $10 \%$. Strain P $333 / 02^{\mathrm{T}}$ contained $56.2 \%$ 12-methyl tetradecanoic acid, $17 \cdot 2 \%$ 14-methyl hexadecanoic acid, 13.5\% 14-methyl pentadecanoic acid, $7.5 \%$ hexadecanoic acid, $3.9 \%$ 13-methyl tetradecanoic acid, $1.2 \%$ 15-methyl hexadecanoic acid and $0.5 \%$ 12-methyl tridecanoic acid. Strain P 369/06 ${ }^{\mathrm{T}}$ contained $46 \cdot 1 \%$ 12-methyl tetradecanoic acid, $16 \cdot 3 \%$ 14-methyl pentadecanoic acid, $15.4 \%$ 13-methyl tetradecanoic acid, $14.7 \%$ 14-methyl hexadecanoic acid, 3.7\% 15-methyl hexadecanoic acid, 3.2\% hexadecanoic acid and $0.7 \%$ 12-methyl tridecanoic acid. The $\mathrm{G}+\mathrm{C}$ contents of $\mathrm{P} 333 / 02^{\mathrm{T}}$ and $\mathrm{P} 369 / 06^{\mathrm{T}}$ were 67 and $64 \mathrm{~mol} \%$, respectively.

The cell-wall peptidoglycan type for $\mathrm{P} 333 / 02^{\mathrm{T}}$ and $\mathrm{P}$ $369 / 06^{\mathrm{T}}$ was found to be B2 $\beta$ (Schleifer \& Kandler, 1972) (L-homoserine)-D-Glu $\rightarrow$ Gly $\rightarrow$ D-Orn with glycolyl residues. The cell-wall sugars of strain P $369 / 06^{\mathrm{T}}$ were galactose and rhamnose; strain $\mathrm{P} 333 / 02^{\mathrm{T}}$ additionally contained mannose.

\section{Phylogenetic analysis}

The $16 \mathrm{~S}$ rDNA sequencing of $\mathrm{P} 333 / 02^{\mathrm{T}}$ and $\mathrm{P} 369 / 06^{\mathrm{T}}$ gave a similarity level of $99 \cdot 2 \%$, which represents differences at only 12 of the $1480 \mathrm{bp}$ determined (10 substitutions and 2 additional bases in $\mathrm{P} 333 / 02^{\mathrm{T}}$ ). All of the divergent nucleotides of the two sequences were found to be variable among Microbacterium spp. Moreover, the different nucleotides of $\mathrm{P} 333 / 02^{\mathrm{T}}$ and $\mathrm{P}$
$369 / 06^{\mathrm{T}}$ corresponded to those of at least two other Microbacterium species. Seven of these differences were located in a variable region that was significantly distinct within the genus Microbacterium (positions 74-97; Escherichia coli numbering system; Brosius et al., 1978).

To characterize the relationships of the isolates at the species level, the DNA-DNA similarity of strains $\mathrm{P}$ $333 / 02^{\mathrm{T}}$ and $\mathrm{P} 369 / 06^{\mathrm{T}}$, as well as that of $\mathrm{P} 439 / 06$ and P 449/03, representing two pairs of both subgroups, were examined. The results of DNA-DNA reassociation revealed similarities of 41 and $42 \cdot 7 \%$, suggesting that the strains represent different species. DNA-DNA hybridization between $\mathrm{P} 333 / 02^{\mathrm{T}}$ and the second strain of genotype II (P 439/06) revealed a similarity of $33.6 \%$, supporting the above findings. However, the reassociation between $\mathrm{P} 369 / 06^{\mathrm{T}}$ and $\mathrm{P} 439 / 06$, both of which are members of genotype II, showed $86.3 \%$ similarity, demonstrating that they belong to the same species.

Comparison of $16 \mathrm{~S}$ rDNA sequences with validly described Microbacterium spp. showed that both strains (P 333/02 ${ }^{\mathrm{T}}$ and P $369 / 06^{\mathrm{T}}$ ) evidently belong to the genus Microbacterium (Fig. 1). The strains were clustered together using the neighbour-joining method and the maximum-likelihood method, which was supported by high bootstrap values. The best conformities were found with the rRNA sequences of Microbacterium maritypicum, Microbacterium oxydans, $M$. liquefaciens, Microbacterium keratanolyticum, M. saperdae and Microbacterium luteolum, which were clustered together by both methods. Species displaying similarity values higher than $97 \%$ relative to $\mathrm{P} 333 / 02^{\mathrm{T}}$ (genotype I) are listed in Table 3. To clarify the taxonomic position at the species level, 
Table 3. Similarity values of $16 \mathrm{~S}$ rDNA sequences and DNA relatedness between $\mathrm{P} 333 / 02^{\top}$ (=DSM $12966^{\top}$ ) and $P$ $369 / 06^{\top}$ (= DSM $13468^{\top}$ ) in comparison to the nearest phylogenetic neighbours of Microbacterium spp. and A. resistens

\begin{tabular}{|c|c|c|c|c|}
\hline Species & $\begin{array}{l}\text { 16S rDNA similarity } \\
\text { to } \mathrm{P} 333 / 02^{\mathrm{T} *}\end{array}$ & $\begin{array}{l}\text { DNA reassociation } \\
(\%) \text { with } P 333 / 02^{T}\end{array}$ & $\begin{array}{l}\text { 16S rDNA similarity to } \\
\text { P } 369 / 06^{\mathrm{T}} \uparrow\end{array}$ & $\begin{array}{l}\text { DNA reassociation } \\
(\%) \text { with } P 369 / 06^{\mathrm{T}}+\end{array}$ \\
\hline P $369 / 06^{\mathrm{T}}$ & $99 \cdot 20$ & $41 \cdot 0$ & - & - \\
\hline M. aurantiacum & $97 \cdot 00$ & $17 \cdot 5$ & $97 \cdot 29$ & - \\
\hline M. aurum & $97 \cdot 29$ & $20 \cdot 6$ & $97 \cdot 22$ & - \\
\hline M. keratanolyticum & $98 \cdot 07$ & $20 \cdot 6$ & $98 \cdot 43$ & $33 \cdot 0$ \\
\hline M. kitamiense & $97 \cdot 14$ & $18 \cdot 3$ & $97 \cdot 57$ & - \\
\hline M. lacticum & $97 \cdot 37$ & $29 \cdot 7$ & $97 \cdot 58$ & - \\
\hline M. liquefaciens & $98 \cdot 43$ & $28 \cdot 6$ & $98 \cdot 29$ & $36 \cdot 7$ \\
\hline M. luteolum & $97 \cdot 86$ & $29 \cdot 5$ & $97 \cdot 72$ & - \\
\hline M. maritypicum & $98 \cdot 72$ & $29 \cdot 8$ & $98 \cdot 57$ & $44 \cdot 4$ \\
\hline M. oxydans & $98 \cdot 65$ & $43 \cdot 1$ & $98 \cdot 50$ & $46 \cdot 2$ \\
\hline A. resistens & $97 \cdot 65$ & $21 \cdot 9$ & $97 \cdot 79$ & - \\
\hline M. saperdae & $98 \cdot 07$ & $37 \cdot 0$ & $98 \cdot 00$ & - \\
\hline M. terregens & $97 \cdot 15$ & $19 \cdot 5$ & $97 \cdot 08$ & - \\
\hline M. testaceum & $97 \cdot 65$ & $16 \cdot 5$ & $98 \cdot 21$ & - \\
\hline
\end{tabular}

* Comparison of 1402 nucleotides and the corresponding sequences.

$\uparrow$ Comparison of 1400 nucleotides and the corresponding sequences.

\$DNA-DNA hybridization against the closest neighbours.

DNA-DNA similarity was examined. All DNA-DNA reassociation values between strain $\mathrm{P} 333 / 02^{\mathrm{T}}$ and the closely related Microbacterium spp. were lower than $70 \%$ (Table 3 ), indicating that the isolate represents a separate species (Wayne et al., 1987).

Hybridization studies performed for the closest phylogenetic neighbours of P $369 / 06^{\mathrm{T}}$ (genotype II) showed similar DNA-DNA reassociation values (Table 3), indicating that genotype II represents a new species as well.

\section{DISCUSSION}

Restriction analysis of $16 \mathrm{~S}$ rDNA revealed two different genotypes among the isolates. Comparison of 16S rDNA sequences between representative strains of both subgroups and all validly described species of Microbacterium showed a clear affiliation to this genus (Fig. 1). The isolates clustered unambiguously within the monophyletic branch of Microbacterium, showing a high level of similarity to the type species $M$. lacticum (DSM $\left.20427^{\mathrm{T}}\right)$. The results of chemotaxonomic examinations focusing on selected strains supported these findings. Thus, the tested isolates displayed the major menaquinones MK-12, MK-11 and MK-10, as well as predominating iso- and anteiso-branched fatty acids, as described for the genus Microbacterium (Takeuchi \& Hatano, 1998a). The $\mathrm{G}+\mathrm{C}$ content (64 and 67 $\mathrm{mol} \%)$ is also within the range typical for Microbacterium (Takeuchi \& Hatano, 1998a). The cell-wall peptidoglycan is of the B2 $\beta$ type based on D-ornithine (Schleifer \& Kandler, 1972). These findings are in accordance with the original description of the genus
Aureobacterium (Collins et al., 1983), accommodated recently in a redefined genus Microbacterium (Takeuchi \& Hatano, 1998a). Thus, all of the chemotaxonomic features of the isolates correspond to the general phenotypic characteristics of the genus Microbacterium.

To clarify the relationship of both genotypes at the species level, DNA-DNA hybridization studies were performed. The results showed reassociation values far below $70 \%$, the threshold value proposed by Wayne et al. (1987) as indicating species status. From these data, it was concluded that both genotypes differentiated by 16S rDNA restriction analysis represent individual species. Comparison of the $16 \mathrm{~S}$ rDNA sequences of strains representing the genotypes revealed a high level of similarity. Both strains formed a separate branch in the phylogenetic tree, with high bootstrap support (Fig. 1). However, because they demonstrate greater differences in their $16 \mathrm{~S}$ rDNA sequences than are shown, for example, by the more closely related species $M$. oxydans, $M$. liquefaciens and $M$. maritypicum, $16 \mathrm{~S}$ rDNA analysis also supported the differentiation of both genotypes at the species level. In contrast to the phylogeny, no physiological feature was found to differentiate all strains of the subgroups. The physiological characteristics of the isolates were similar, although strain-specific differences for several features are demonstrated (Table 2). Clustering on the basis of these divergent features showed no correspondence to the assignment of genotypes (data not shown). Similar results were found for species of the genus Sulfitobacter by Pukall et al. (1999). Sulfitobacter mediterraneus showed the same physiological properties as Sulfito- 
bacter pontiacus, which can be separated by the restriction patterns of 16S rDNA, DNA-DNA hybridization and fatty acid composition. The similarity of physiological characteristics in association with molecular differences is possibly an expression of an adaptation to the same nutritional compounds for organisms occupying similar ecological niches.

However, differences in the quantitative fatty acid composition (i.e. higher amounts of 13-methyl tetradecanoic acid for strain P $369 / 06^{\mathrm{T}}$ ) and the additional occurrence of mannose as a cell-wall sugar in strain $\mathrm{P}$ $333 / 02^{\mathrm{T}}$ are chemotaxonomic features which allowed the differentiation of the proposed type strains.

Analysis of DNA-DNA similarity in comparison to the phylogenetically related Microbacterium spp. and $A$. resistens supported the individual species classification within the genus Microbacterium, as all reassociation values were found to be lower than $70 \%$ (Wayne et al., 1987). The two subgroups and the previously described species of the genera Microbacterium and $A$. resistens were clearly differentiated by phenotypic characteristics, as shown in Table 4 . Almost all species included the closest phylogenetic neighbours (M. maritypicum, M. oxydans, M. keratanolyticum and $M$. liquefaciens) and can be easily differentiated by comparison of the composition of the cell wall (sugars and amino acids). Microbacterium testaceum, which displayed the same cell wall composition as that of genotype I ('Microbacterium foliorum') can be distinguished by growth in the presence of $2 \% \mathrm{NaCl}, \mathrm{H}_{2} \mathrm{~S}$ production, and the formation of acid from glucose. M. luteolum, showing the same cell wall composition as genotype II ('Microbacterium phyllosphaerae'), can be distinguished by the motility of the cells, growth in the presence of $\mathrm{NaCl}$, hydrolysis of gelatin, and $\mathrm{H}_{2} \mathrm{~S}$ formation. M. ketosireducens, the only species with B2 $\beta$-type peptidoglycan and an unknown cell-wall sugar composition, differed from both genotypes by the motility of the cells, $\mathrm{H}_{2} \mathrm{~S}$ production, and the assimilation of $\mathrm{N}$-acetylglucosamine and malate.

Since both groups of grass-associated isolates can be distinguished from all validly described Microbacterium and Aureobacterium species on the basis of phenotypic and phylogenetic characteristics, and from each other by analysis of the cell-wall sugars, $16 \mathrm{~S}$ rDNA restriction analysis using the enzymes $C f o \mathrm{I}$ and HaeIII, and DNA-DNA hybridization, we conclude that both groups deserve a separate species status. Consequently, the names Microbacterium foliorum sp. nov. and Microbacterium phyllosphaerae sp. nov. are proposed.

Furthermore, the reclassification of $A$. resistens (Funke et al. 1998) as Microbacterium resistens (Funke et al., 1998) comb. nov. is proposed. A. resistens (Funke et al. 1998) displayed the general characteristics of the redefined genus Microbacterium, and should be reclassified as a result of the taxonomic unification (Takeuchi \& Hatano, 1998a).

\section{Description of Microbacterium foliorum sp. nov.}

Microbacterium foliorum (fo.li.o'.rum. L. pl. gen. neut. n. foliorum of the leaves).

Cells are Gram-positive, strictly aerobic, non-sporeforming, irregularly shaped rods, which sometimes form V-shapes and are motile by means of a single polar or lateral flagellum. In older cultures, rods are shorter, but a marked rod-coccus cycle does not occur. Colonies are yellow, shiny, slightly convex and round with entire margins. Oxidase, urease, arginine dihydrolase and Voges-Proskauer reactions are negative. Hydrogen sulphide and indole are not produced. Nitrate is not reduced to nitrite. Positive for catalase and $\beta$-galactosidase. Gelatin, DNA and aesculin are hydrolysed. Utilization of starch is weak. None of the strains hydrolyses casein and Tween 80, whereas hydrolysis of Tween 60 is strain-dependent. Arabinose, gluconate, glucose, malate, maltose, mannitol, mannose and N-acetylglucosamine are assimilated, but caprate and adipate are not used. Citrate and phenylacetate are utilized only by certain strains. Acid production is positive from amygdalin, L-arabinose, arbutin, cellobiose, D-fructose, galactose, glycerol, maltose, mannitol, D-mannose, salicin, sucrose, trehalose and D-xylose, but negative from adonitol, Darabitol, L-arabitol, dulcitol, D-fucose, erythritol, gluconate, 2-ketogluconate, 5-ketogluconate, inositol, L-sorbose, D-tagatose, xylitol and L-xylose. Acid production is variable between strains of D-arabinose, methyl $\alpha$-D-glucoside, L-fucose, $\beta$-gentiobiose, glycogen, inulin, lactose, methyl $\alpha$-D-mannoside, melibiose, melezitose, raffinose, rhamnose, ribose, sorbitol, starch and methyl $\beta$-D-xyloside. Negative for the fermentative and oxidative production of acid from glucose, according to the method of Hugh \& Leifson (1953), but positive for oxidative acid production when tested using API 20NE and API 50CH. Growth occurs in the presence of $2 \% \mathrm{NaCl}$. The optimum temperature for growth is approximately $25^{\circ} \mathrm{C}$. At $37^{\circ} \mathrm{C}$, growth is strain-dependent, but growth does not occur at $42{ }^{\circ} \mathrm{C}$. The major menaquinones are MK-12, MK-11 and MK-10. The predominant cellular fatty acids are 12methyl tetradecanoic acid, 14-methyl hexadecanoic acid and 14-methyl pentadecanoic acid. Contains peptidoglycan of the B2 $\beta$ (L-homoserine)-D-Glu $\rightarrow$ Gly $\rightarrow$ D-Orn type, with glycolyl residues. The DNA $\mathrm{G}+\mathrm{C}$ composition for the type strain is $67 \mathrm{~mol} \%$. The cell-wall sugars are galactose, mannose and rhamnose. Isolated from the phyllosphere of grasses and from the litter layer after mulching of the sward. The type strain is DSM $12966^{\mathrm{T}}\left(=\mathrm{P} 333 / 02^{\mathrm{T}}=\mathrm{LMG} 19580^{\mathrm{T}}\right)$.

\section{Description of Microbacterium phyllosphaerae sp. nov.}

Microbacterium phyllosphaerae (phyl.lo.sphae'rae. Gr. n. phyllon leaf; Gr. fem. n. sphaira ball, sphere; M.L. gen. fem. n. phyllosphaerae of the phyllosphere).

The morphological and physiological properties are as 
Data from this study and Funke et al. (1998), Matsuyama et al. (1999), Schumann et al. (1999), Takeuchi \& Yokota (1994), Takeuchi \& Hatano (1998a, b), Yokota et al. (1993a, b). Abbreviations: +, positive reaction; +w, weakly positive; -, negative; +/-, different results in cited references; d, reaction differs among strains; ND, not determined; y, yellow; yw, yellow white; yb, yellow beige; ly, light yellow; o, orange; GEL, gelatine; starch; $\mathrm{H}_{2} \mathrm{~S}, \mathrm{H}_{2} \mathrm{~S}$ production; VP, Voges-Proskauer test; ADH, arginine dihydrolase; ARA, arabinose; NAG, $N$-acetylglucosamine; MLT, malate; CIT, citrate; PAC, phenyl acetate; GLC, glucose; Rha, rhamnose; Gal, galactose; Man, mannose; 6dTal, 6deoxytalose; Fuc, fucose; Xyl, xylose.

\begin{tabular}{|c|c|c|c|c|c|c|c|c|c|c|c|c|c|c|c|c|c|c|c|}
\hline \multirow{2}{*}{ Species } & \multirow{2}{*}{$\begin{array}{l}\text { Colour } \\
\text { of } \\
\text { colony }\end{array}$} & \multirow{2}{*}{$\begin{array}{l}\text { Moti- } \\
\text { lity }\end{array}$} & \multicolumn{2}{|c|}{ Growth } & \multicolumn{2}{|c|}{$\begin{array}{l}\text { Hydrolysis } \\
\text { of }\end{array}$} & \multirow{2}{*}{$\mathrm{H}_{2} \mathrm{~S}$} & \multirow{2}{*}{ VP } & \multirow{2}{*}{ ADH } & \multicolumn{5}{|c|}{ Assimilation of : } & \multirow{2}{*}{$\begin{array}{l}\text { Acid } \\
\text { from } \\
\text { GLC }\end{array}$} & \multirow{2}{*}{$\begin{array}{l}\text { Major } \\
\text { Mena- } \\
\text { quinone } \\
\text { (MK) }\end{array}$} & \multirow{2}{*}{ Cell wall sugar(s) } & \multirow{2}{*}{$\begin{array}{c}\text { Type of } \\
\text { Pepti- } \\
\text { dogly- } \\
\text { can }\end{array}$} & \multirow{2}{*}{$\begin{array}{l}\text { Cell wal } \\
\text { diamino } \\
\text { acid }\end{array}$} \\
\hline & & & $37^{\circ} \mathrm{C} 2 \%$ & $\% \mathrm{NaCl}$ & GEL & STA & & & & ARA & NAG & CIT & MLT & PAC & & & & & \\
\hline M. foliorum (Genotype I) & $\mathrm{y}$ & + & $d$ & + & + & $+w$ & - & - & - & + & + & d & + & d & + & $10,11,12$ & Rha, Gal, Man & $B 2 \beta$ & Orn \\
\hline M. phyllosphaerae (Type II) & y & + & d & + & + & $+w^{*}$ & - & - & - & + & + & - & + & $d$ & $+^{\dagger}$ & $10,11,12$ & Gal, Rha & $B 2 \beta$ & Orn \\
\hline M. arabinogalactanolyticum & $y w / w$ & - & - & + & + & + & + & - & + & + & + & ND & ND & ND & - & 12,13 & Gal & $B 2 \beta$ & Orn \\
\hline M. aurantiacum & 0 & - & + & + & - & + & + & - & - & $d$ & - & $\cdot$ & d & - & d & 12 & Rha, Gal, Fuc & $B 2 \beta$ & Orn \\
\hline M. barkeri & $w / y$ & + & + & + & + & + & + & - & + & + & + & $+1=$ & + & - & - & 11,12 & Rha, Gal, Glc & $B 2 \beta$ & Orn \\
\hline M. chocolatum & 0 & - & + & $+w$ & - & $+w$ & + & - & - & - & - & $\cdot$ & - & - & - & 12 & Rha, Gal, $\operatorname{Man}^{\ddagger},\left.\mathrm{Xy}\right|^{\ddagger}$ & $B 2 \beta$ & Orn \\
\hline M. esteraromaticum & $y w / y$ & + & d & - & - & + & + & - & - & + & - & - & $+/-$ & - & - & 12,13 & Gal, Glc & $B 2 \beta$ & Orn \\
\hline M. flavescens & $y$ & - & - & + & + & + & + & - & - & + & - & - & $+1-$ & - & + & 13,14 & Rha, Gal, Glc & $B 2 \beta$ & Orn \\
\hline M. halophilum & yw & - & + & + & $+w$ & + & - & - & - & - & - & - & - & - & + & $11,12,13$ & Man, Gal, Glc & $B 2 \beta$ & Orn \\
\hline M. ketosireducens & $y$ & - & - & + & + & + & + & - & - & + & - & $d$ & - & - & + & 13 & ND & $B 2 \beta$ & Orn \\
\hline M. liquefaciens & $y$ & - & - & + & + & - & + & - & + & - & + & + & $+1-$ & - & - & 11,12 & Rha & $B 2 \beta$ & Orn \\
\hline M. luteolum & yw & - & - & - & - & - & + & - & - & + & + & - & + & - & + & 12 & Rha. Gal & $B 2 B$ & Orn \\
\hline M. maritypicum & ly & + & + & + & + & - & - & - & - & - & + & + & + & + & + & 12 & Gal & $B 2 B$ & Orn \\
\hline M. oxydans & $y$ & + & + & + & + & - & + & - & - & - & $+w$ & + & + & - & + & 11,12 & Rha, Man, Glc, Gal & $B 2 B$ & Orn \\
\hline M. saperdae & yw/y & + & - & - & - & + & + & - & + & + & + & - & + & - & + & 11,12 & Gal, Glc & $B 2 \beta$ & Orn \\
\hline M. schleiferi & $y w / y$ & - & $+w$ & + & - & - & - & + & - & $+w$ & $+w$ & - & $+1-$ & - & + & 11,12 & 6dTal, Man, Gal & $\mathrm{B} 2 \mathrm{~B}$ & Orn \\
\hline M. terregens & y/yb & $\cdot$ & - & $+w$ & - & - & - & - & - & - & - & - & + & - & + & 12,13 & Rha, 6dTal,Gal & $B 2 B$ & Orn \\
\hline M. testaceum & $0 / y-0$ & + & - & - & + & - & + & - & - & + & + & $+/-$ & + & $+w$ & - & 10,11 & Rha, Man, Gal & $B 2 \beta$ & Orn \\
\hline M. thalassium & $y$ & - & - & + & d & + & - & - & - & - & - & - & - & - & + & 11,12 & Gal, $\mathrm{Glc}^{5}$ & $B 2 B$ & Orn \\
\hline M. trichothecenolyticum & $y$ & - & - & $+w$ & - & + & + & - & - & - & + & $+/-$ & + & - & + & 12,13 & Gal, Glc & $B 2 \beta$ & Orn \\
\hline M. arborescens & 0 & $+1-$ & - & ND & + & - & + & - & - & + & + & $+w$ & + & - & + & 11,12 & 6dTal, Man, Gal & B1ß & Lys \\
\hline M. aurum & yw & - & + & + & + & + & + & - & - & - & $+w$ & - & - & - & + & 11,12 & Fuc, Gal, Glc & B1ß & Lys \\
\hline M. imperiale & 0 & + & + & ND & - & + & $+/$ & - & - & + & $+w$ & - & + & - & + & 11,12 & Rha, Man, Gal & $B 1 B$ & Lys \\
\hline M. dextranolyticum & w & - & - & ND & - & - & + & + & - & + & - & - & + & + & + & 11,12 & 6dTal, Man, Gal & B1a & Lys \\
\hline M. hominis & yw & - & + & + & - & - & + & + & - & + & + & + & + & - & + & 11,12 & Rha, 6dTal,Gal, Man & B1a & Lys \\
\hline M. lacticum & $y w / y$ & - & - & $+w$ & - & + & - & - & - & $+w$ & + & - & + & - & + & 11,12 & Rha, Man, Gal & B1a & Lys \\
\hline M. laevaniformans & $y w / y$ & - & + & + & - & + & + & + & $d$ & - & - & $d$ & + & - & + & 11,12 & Rha, Man, Gal, Xyl & B1a & Lys \\
\hline M. keratanolyticum & $y$ & + & - & + & + & - & + & - & + & $+w$ & + & - & - & - & - & 12,13 & Gal & $\mathrm{B} 2 \mathrm{a}$ & Orn \\
\hline A. resistens & y & - & + & + & + & - & - & - & - & - & + & + & - & - & + & ND & ND & $B 2 a$ & Om \\
\hline M. kitamiense & 0 & - & + & + & + & + & - & - & - & - & - & - & - & - & + & 11,12 & ND & ND & Orn \\
\hline
\end{tabular}

* The majority of strains showed a weak reaction with the exceptions of one strain with strong hydrolysis and one without hydrolysis.

† Determined by AP1 20NE; one tested strain was not able to produce acid.

t Traces.

$\S$ Depending on strain; Gal, Glc, Rha, Man. 
described for M. foliorum, but the hydrolysis of Tween 80 , casein and starch varies between strains. Assimilation of citrate is negative. Acid production from $\beta$ gentiobiose, as well as from rhamnose, is positive for all strains. Acid production is strain-dependent for Larabinose, inositol, xylitol and D-xylose. Oxidative acid production from glucose, tested with API 20NE, is positive for almost all strains. The major menaquinones are MK-12, MK-11 and MK-10. The predominant cellular fatty acids are 12-methyl tetradecanoic acid, 14-methyl pentadecanoic acid, 13methyl tetradecanoic acid and 14-methyl hexadecanoic acid. The DNA G $+\mathrm{C}$ composition for the type strain is $64 \mathrm{~mol} \%$. The peptidoglycan is of the $\mathrm{B} 2 \beta$ ( $\mathrm{L}-$ homoserine)-D-Glu $\rightarrow$ Gly $\rightarrow$ D-Orn type, with glycolyl residues. The cell-wall sugars are galactose and rhamnose. Isolated from the phyllosphere of grasses and from the litter layer after mulching of the sward. The type strain is DSM $13468^{\mathrm{T}}\left(=\mathrm{P} 369 / 06^{\mathrm{T}}=\mathrm{LMG}\right.$ $\left.19581^{\mathrm{T}}\right)$.

\section{Description of Microbacterium resistens (Funke et al. 1998) comb. nov., basonym Aureobacterium resistens}

The morphological, cultural and physiological properties were reported by Funke et al. (1998). In addition, the major menaquinones are MK-12 and MK-13, the arginine dihydrolase and Voges-Proskauer reactions are negative, and growth in the presence of $2 \% \mathrm{NaCl}$ is positive. The type strain, isolated from human clinical specimens, is DSM $11986^{\mathrm{T}}\left(=\right.$ CCUG $38312^{\mathrm{T}}$ $=\mathrm{DMMZ} 1710^{\mathrm{T}}$ ).

\section{ACKNOWLEDGEMENTS}

We wish to thank Mrs U. Steiner and Mrs M. Schmidt (DSMZ, Braunschweig), Mrs S. Weinert (ZALF, Müncheberg), Mrs A. Nandke and Mrs B. Selch (ZALF, Paulinenaue) for their excellent technical assistance. Furthermore, we wish to thank Professor Dr H. G. Trüper (Rheinische Friedrich-Wilhelm-Universität, Bonn) for his help with the Latin construction of the species name.

\section{REFERENCES}

Behrendt, U., Müller, T. \& Seyfarth, W. (1997). The influence of extensification in grassland management on the populations of micro-organisms in the phyllosphere of grasses. Microbiol Res 152, 75-85.

Behrendt, U., Ulrich, A., Schumann, P., Erler, W., Burghardt, J. \& Seyfarth, W. (1999). A taxonomic study of bacteria isolated from grasses: a proposed new species Pseudomonas graminis sp. nov. Int J Syst Bacteriol 49, 297-308.

Brosius, J., Palmer, M. L., Kennedy, P. J. \& Noller, H. F. (1978). Complete nucleotide sequence of a $16 \mathrm{~S}$ ribosomal RNA gene from Escherichia coli. Proc Natl Acad Sci U S A 75, 4801-4805.

Collins, M. D. \& Bradbury, J. F. (1992). The genera Agromyces, Aureobacterium, Clavibacter, Curtobacterium, and Microbacterium. In The Prokaryotes, pp. 1355-1368. Edited by A. Balows, H. G. Trüper, M. Dworkin, W. Harder \& K.-H. Schleifer. Berlin: Springer.

Collins, M. D., Jones, D., Keddie, R. M., Kroppenstedt, R. M. \&
Schleifer, K. H. (1983). Classification of some coryneform bacteria in a new genus Aureobacterium. Syst Appl Microbiol 4, 236-252.

Felsenstein, J. (1981). Evolutionary tree from DNA sequences: a maximum likelihood approach. J Mol Evol 17, 368-376.

Felsenstein, J. (1993). PHYLIP (Phylogeny Inference Package) version 3.5c. Department of Genetics, University of Washington, Seattle, WA, USA.

Funke, G., Lawson, P. A., Nolte, F. S., Weiss, N. \& Collins, M. D. (1998). Aureobacterium resistens sp. nov., exhibiting vancomycin resistance and teicoplanin susceptibility. FEMS Micobiol Lett 158, 89-93.

Groth, I., Schumann, P., Schuetze, B., Augsten, K., Kramer, I. \& Stackebrandt, E. (1999). Beutenbergia cavernae gen. nov., sp. nov., an L-lysine-containing actinomycete isolated from a cave. Int J Syst Bacteriol 49, 1733-1740.

Hugh, R. \& Leifson, E. (1953). The taxonomic significance of fermentative versus oxidative metabolism of carbohydrates by various Gram-negative bacteria. J Bacteriol 66, 24-26.

Kimura, M. (1980). A simple method for estimating evolutionary rates of base substitutions through comparative studies of nucleotide sequences. $J$ Mol Evol 16, 111-120.

Komagata, K. \& Suzuki, K.-I. (1987). Lipid and cell-wall analysis in bacterial systematics. In Methods in Microbiology, vol. 19, pp. 161-207. Edited by R. R. Colwell \& R. Grigorova. London: Academic Press.

Larsen, N., Olsen, G. J., Maidak, B. L., McCaughey, M. J., Overbreek, R., Macke, T. J., Marsh, T. L. \& Woese, C. R. (1993). The ribosomal database project. Nucleic Acids Res 21, 3021-3023.

Legard, D. E., McQuilken, M. P., Whipps, J. M., Fenlon, J. S., Fermor, T. R., Thompson, I. P., Bailey, M. J. \& Lynch, J. M. (1994). Studies of seasonal changes in the microbial populations on the phyllosphere of spring wheat as a prelude to the release of a genetically modified microorganism. Agric Ecosyst Environ 50, 87-101.

Mclnroy, J. A. \& Kloepper, J. W. (1995). Survey of indigenous bacterial endophytes from cotton and sweet corn. Plant Soil 173, 337-342.

Martin, K., Schumann, P., Rainey, F. A., Schuetze, B. \& Groth, I. (1997). Janibacter limosus gen. nov., a new actinomycete with meso-diaminopimelic acid in the cell wall. Int $J$ Syst Bacteriol 47, 529-534.

Matsuyama, H., Kawasaki, K., Yumoto, I. \& Shida, O. (1999). Microbacterium kitamiense sp. nov., a new polysaccharideproducing bacterium isolated from the wastewater of a sugarbeet factory. Int J Syst Bacteriol 49, 1353-1357.

Pukall, R., Buntefuß, D., Frühling, A., Rohde, M., Kroppenstedt, R. M., Burghardt, J., Lebaron, P., Bernard, L. \& Stackebrandt, E. (1999). Sulfitobacter mediterraneus sp. nov., a new sulfiteoxidizing member of the $\alpha$-Proteobacteria. Int $J$ Syst Bacteriol 49, 513-519.

Rudolph, K. \& Marvidis, A. (1990). Flagella, motility, chemotaxis and helicity. In Methods in Phytobacteriology, pp. 441-444. Edited by Z. Klement, K. Rudolph \& D. C. Sands. Budapest: Akademiai Kiado.

Ryu, E. (1938). On the Gram-differentiation of bacteria by the simplest method. J Jpn Soc Vet Sci 17, 58-63.

Saitou, N. \& Nei, M. (1987). The neighbor-joining method: a new method for reconstructing phylogenetic trees. Mol Biol Evol 4, 406-425.

Sands, D. C. (1990). Physiological criteria - determinative tests. In Methods in Phytobacteriology, pp. 133-143. Edited by Z. 
Klement, K. Rudolph \& D. C. Sands. Budapest: Akademiai Kiado.

Schleifer, K. H. \& Kandler, O. (1972). Peptidoglycan types of bacterial cell walls and their taxonomic implications. Bacteriol Rev 36, 407-477.

Schumann, P., Rainey, F. A., Burghardt, J., Stackebrandt, E. \& Weiss, N. (1999). Reclassification of Brevibacterium oxydans (Chatelain and Second 1966) as Microbacterium oxydans comb. nov. Int J Syst Bacteriol 49, 175-177.

Sneath, P. H. A. \& Sokal, R. R. (1973). Numerical Taxonomy. San Francisco: W. H. Freeman.

Stead, D. E., Sellwood, J. E., Wilson, J. \& Viney, I. (1992). Evaluation of a commercial microbial identification system based on fatty acid profiles for rapid, accurate identification of plant-pathogenic bacteria. J Appl Bacteriol 72, 315-321.

Süßmuth, R., Eberspächer, J., Haag, R. \& Springer, W. (1987). Biochemisch-mikrobiologisches Praktikum. Stuttgart: Thieme.

Takeuchi, M. \& Hatano, K. (1998a). Union of the genera Microbacterium Orla-Jensen and Aureobacterium Collins et al. in a redefined genus Microbacterium. Int J Syst Bacteriol 48, 739-747.

Takeuchi, M. \& Hatano, K. (1998b). Proposal of six new species in the genus Microbacterium and transfer of Flavobacterium marinotypicum ZoBell and Upham to the genus Microbacterium as Microbacterium maritypicum comb. nov. Int J Syst Bacteriol 48, 973-982.

Takeuchi, M. \& Yokota, A. (1994). Phylogenetic analysis of the genus Microbacterium based on $16 \mathrm{~S}$ rRNA gene sequences. FEMS Microbiol Lett 124, 11-16.

Thompson I. P., Bailey M. J., Fenlon J. S. \& 8 other authors (1993). Quantitative and qualitative seasonal changes in the microbial community from the phyllosphere of sugar beet (Beta vulgaris). Plant Soil 150, 177-191.

Thompson, J. D., Higgins, D. G. \& Gibson, T. J. (1994). CLUSTAL $\mathrm{W}$ : improving the sensitivity of progressive multiple sequence alignment through sequence weighting, position-specific gap penalties and weight matrix choice. Nucleic Acids Res 22, 4673-4680.

Uchida, K., Kudo, T., Suzuki, K. \& Nakase, T. (1999). A new rapid method of glycolate test by diethyl ether extraction, which is applicable to a small amount of bacterial cells of less than one milligram. J Gen Appl Microbiol 45, 49-56.

Vidaver, A. K. \& Davis, M. J. (1994). Coryneform plant pathogens. In Laboratory Guide for Identification of Plant Pathogenic Bacteria, 2nd edn, pp. 104-113. Edited by N. W. Schaad. St Paul, MN : American Phytopathological Society Press.

Wayne, L. G., Brenner, D. J., Colwell, R. R. \& 9 other authors (1987). International Committee on Systematic Bacteriology. Report of the ad hoc committee on reconciliation of approaches to bacterial systematics. Int J Syst Bacteriol 37, 463-464.

Weisburg, W. G., Barns, S. M., Pelletier, D. A. \& Lane, D. J. (1991). $16 \mathrm{~S}$ ribosomal DNA amplification for phylogenetic study. $J$ Bacteriol 173, 697-703.

Yokota, A., Takeuchi, M., Sakane, T. \& Weiss, N. (1993a). Proposal of six new species in the genus Aureobacterium and transfer of Flavobacterium esteraromaticum Omelianski to the genus Aureobacterium as Aureobacterium esteraromaticum comb. nov. Int $J$ Syst Bacteriol 43, 555-564.

Yokota, A., Takeuchi, M. \& Weiss, N. (1993b). Proposal of two new species in the genus Microbacterium: Microbacterium dextranolyticum sp. nov. and Microbacterium aurum sp. nov. Int $J$ Syst Bacteriol 43, 549-554. 